Article

\title{
Human Rights Promotion through Transnational Investment Regimes: An International Political Economy Approach
}

Claire Cutler ${ }^{1,2}$

${ }^{1}$ Department of Political Science, University of Victoria, SSM A316, 3800 Finnerty Rd., Victoria, BC V8P 5C2, Canada; E-Mail: ccutler@uvic.ca

${ }^{2}$ Hague Institute for the Internationalisation of Law, Bezuidenhoutseweg 16A, 2594 AV, The Hague, The Netherlands

\section{How to Cite this Article}

Cutler, C. (2013). Human Rights Promotion through Transnational Investment Regimes: An International Political Economy Approach. Politics and Governance, 1(1), 16-31.

\section{Acknowledgement}

This Article was published by Librello, Politics and Governance's former publisher.

\author{
About the Journal \\ Politics and Governance is an innovative new offering to the world of online publishing in the Political Sciences. An internationally \\ peer-reviewed open access journal, Politics and Governance publishes significant, cutting-edge and multidisciplinary research \\ drawn from all areas of Political Science. \\ www.cogitatiopress.com/politicsandgovernance

\section{Editors-in-Chief} \\ Professor Andrej J. Zwitter, Faculty of Law, University of Groningen, The Netherlands \\ Professor Amelia Hadfield, Department of Psychology, Politics and Sociology, Canterbury Christ Church University, UK

\section{Managing Editor} \\ Mr. António Vieira, Politics and Governance, Cogitatio Press, Portugal
}




\title{
Human Rights Promotion through Transnational Investment Regimes: An International Political Economy Approach
}

\author{
Claire Cutler ${ }^{1,2}$ \\ ${ }^{1}$ Department of Political Science, University of Victoria, SSM A316, 3800 Finnerty Rd., Victoria, BC V8P 5C2, \\ Canada; E-Mail: ccutler@uvic.ca \\ ${ }^{2}$ Hague Institute for the Internationalisation of Law, Bezuidenhoutseweg 16A, 2594 AV, The Hague, \\ The Netherlands
}

Submitted: 21 January 2013 | In revised form: 21 March 2013 | Accepted: 3 April 2013 |

Published: 9 May 2013

\begin{abstract}
International investment agreements are foundational instruments in a transnational investment regime that governs how states regulate the foreign-owned assets and the foreign investment activities of private actors. Over 3,000 investment agreements between states govern key governmental powers and form the basis for an emerging transnational investment regime. This transnational regime significantly decentralizes, denationalizes, and privatizes decision-making and policy choices over foreign investment. Investment agreements set limits to state action in a number of areas of vital public concern, including the protection of human and labour rights, the environment, and sustainable development. They determine the distribution of power between foreign investors and host states and their societies. However, the societies in which they operate seldom have any input into the terms or operation of these agreements, raising crucial questions of their democratic legitimacy as mechanisms of governance. This paper draws on political science and law to explore the political economy of international investment agreements and asks whether these agreements are potential vehicles for promoting international human rights. The analysis provides an historical account of the investment regime, while a review of the political economy of international investment agreements identifies what appears to be a paradox at the core of their operation. It then examines contract theory for insight into this apparent paradox and considers whether investment agreements are suitable mechanisms for advancing international human rights.
\end{abstract}

Keywords: human rights; incomplete contract theory; international arbitration; investor-state arbitration 


\section{Introduction}

Bilateral and international investment agreements (BITs/IIAs) are foundational instruments in an increasingly privatized transnational investment regime that governs how states can regulate the foreign-owned assets and the foreign investment activities of private actors. There are over 3,000 agreements that regulate investor-state relations and that govern key governmental powers ([1], p. 81). These agreements form the backbone of an emerging transnational investment regime that significantly privatizes, denationalizes, and decentralizes investment decision-making [2]. In addition, investment protection is increasingly included in bilateral and multilateral economic agreements containing investment chapters and in free trade agreements, such as the North American Free Trade Agreement (NAFTA). This growing maze of agreements is often described as a network, although there are no explicit links between and amongst these arrangements. Rather, it is their shared language, principles, and decision-making and interpretive structures that underlie the network metaphor and lead to the conclusion that there has been a significant "treatification of international investment law" ([3], p. 151).

Investment agreements are typically entered into between developed capital-exporting states and developing capital-importing states, but increasingly they are being negotiated between developing states. They set limits to state action in a number of areas of vital public concern, including the protection of human and labour rights, the environment, and sustainable development. They determine the distribution of power between foreign investors and host states and their societies. However, the societies in which they operate seldom have any input into the terms or operation of these agreements, raising crucial questions of their democratic legitimacy as mechanisms of governance. This paper draws upon insights from political science and law to develop a political economy analysis of the investment regime and examines whether investment agreements are potential vehicles for promoting international human rights and advancing the democratic legitimacy of the investor-state regime. The advancement of human rights through investment agreements faces major obstacles stemming from the nature of state responsibility under international law and the difficulty of attaching legal duties to private corporations. However, this analysis suggests that there is a growing recognition of international corporate social responsibilities that may well give rise to increased corporate human rights accountability.

The analysis opens with an account of the empirical incidence of international investment agreements, briefly traces their history in the Post World War II period, and reviews their politico-legal and economic functions. A review of the political economy of investment agreements identifies what appears to be a paradox at the core of their operation. It then examines contract theory for insight into this apparent paradox. In a review of a few high-profile cases involving contestation over the right to water and other human rights the analysis considers whether investment agreements are analytically and theoretically suitable governance mechanisms for advancing international human rights. The paper concludes with discussion of the prospects and challenges of private transnational governance through the investor-state regime.

\section{Investment Arbitration as a Foundation for International Contracting}

International commercial arbitration is one of the oldest instances of private transnational governance, dating in historic forms from the medieval ages, and even earlier [4-7]. Today its roots are associated with the medieval law merchant or lex mercatoria, the private settlement of disputes amongst merchants in merchant courts and under merchant laws that were not enforced in local courts of law. However, this association belies a major distinction between the medieval and modern systems of dispute resolution. The medieval system of commercial arbitration operated between and amongst private actors and through private institutions and private law, while the contemporary system of international commercial arbitration involves a mix of public and private actors, institutions, and processes [8]. The modern regime is comprised by a system of private commercial arbitral institutions based upon the lex mercatoria and by a public international investor-state system of investor protection that regulates the way states treat foreign investment assets and activities. But, importantly, the latter investor-state regime is modelled on the lex mercatoria and thus imports many private laws and standards into inter-state dispute settlement:

Thus, unlike international commercial arbitration based on rules of lex mercatoria, the system of investor protection does not resolve private disputes or regulate the conduct of private parties. Rather, the purpose of the system is to limit how governments regulate multinational enterprises. For this reason, an investor-state dispute pursuant to a treaty is an inherently public dispute; one that involves the exercise of the sovereign power to regulate individuals within a state's territory. Even though the system relies on the model of international commercial arbitration and expands private authority as a method of governance, the system exists within the realm of public international lawnot international commerce-and it remains tied to the authority of states. It is states that established 
the system through a series of treaties that first recognized commercial arbitration as an international institution and then extended the jurisdiction of private arbitration to encompass investment disputes within the private realm ([9], pp. 604-605).

The importation of private law norms into investorstate arbitrations brings some symmetry to the two systems and thus there is a tendency to conflate them [10]. Further symmetry derives from the common rooting of both systems in bilateral or international investment treaties (BITs/IIAs). BITs form the core or central mechanism for the enforcement of contracts in the global political economy, without which individuals and corporations would be powerless against states. They provide credible enforcement mechanisms, which were unavailable under international law prior to their adoption. Moreover, BITs and IIAs have significant capacity to oust the jurisdiction of national courts of law and to internationalize contractual disputes. In many ways, BITs may be said to constitutionalize investment protection by providing for the rule of law and the normative core and foundation for international contracting and the transnational investment regime [11-13]. It is useful to consider the distinction between governance through contract and governance by means of contract in order to clarify the various roles played by investment agreements. The former focuses on the regulatory role of the contract in ordering the rights and relationships of the parties, while the latter focuses on the use of contract to achieve extracontractual regulatory or governance goals. An investment agreement may be analyzed as a form of governance through contract as "an institutional framework and mechanism of 'self-guidance' for private and public parties" ([14], p. 260). As such the agreement functions like a contract to regulate the terms of the investment arrangement. In this respect a BIT creates a framework for the investor-state relationship and, as we shall discuss later, provides for a number of investment protections that structure the relationship, allocate power and interests between the state and the investor in particular ways, and provide for means of dispute resolution. In contrast, governance by means of a BIT directs attention to its extra-contractual function "as an instrument for steering behavior and for achieving regulatory goals" ([14], p. 260). In this way, investment agreements may be conceptualized as performing extracontractual roles in achieving public goals that are extraneous to the parties and international investment laws. They "fulfil[s] an ordering function for the international investment relationship and the implementation of this law may be described as a global public good" ([15], p. 2). Thus, in theory, investment agreements may be utilized to advance broader social and political goals, such as liberalization and privatization. Indeed, Stephan Shill observes that investment treaties "have a constitutional function in providing a legal framework within which international investment activities can take shape and expand. As such, investment treaties are embedded in a larger framework of international law that overarches the individual bilateral treaty relations and establishes uniform rules for the conduct of host States that consist in adopting a liberal attitude vis-à-vis market mechanisms and that accept the limited role of the State vis-à-vis the economy" ([16], p. 17).

Others also emphasize that investor-state arbitration, while modelled on the private law of commercial transactions, is "not merely another form of private law commercial arbitration, with one party now being a state, but...is more fittingly understood as a form of dispute settlement that...also operates in a public law context" ([17], p. 285).

However, the tendency to conflate the private and public dimensions of dispute resolution raises some very interesting questions. Are international investment agreements to be regarded as treaties governed by principles of international law or as contracts governed by contract law? Noemi Gal-Or explores this ambiguity in the context of international agreements that provide for investor-state arbitration, arguing that on one hand they are treaties, but on the other hand they contain "elements of a state-private party contract" ([18], p. 215). If considered a contract, whose contract law applies - that of the investor, the host, or delocalized, transnational contract law? To what extent are BITs subject to the same third party limitations imposed by theories of privity of contract? What are the appropriate interpretive techniques? What mechanisms govern intervention by non-parties in arbitration proceedings or access to documents, the publication of arbitral awards, or appeal proceedings? The importation of private law norms into a public law arena thus poses serious governance challenges. However, before considering these more fully, it is necessary to consider how and why investment arbitration forms a fundamental constitutional foundation for the transnational investment regime. This involves an examination of the history of the investor-state regime and the nature and operation of international investment agreements as essential mechanisms of a private transnational regulatory regime.

\section{History and Function of the Investor Protec- tion Regime}

Historically, disputes over foreign investment were settled by force and "gunboat diplomacy" ([19], p. 780). However, by the nineteenth century colonial powers entered into treaties of Friendship, Commerce, and Navigation (FCN treaties). While FCN treaties were not directed specifically at foreign investment, but were drafted to encourage international trade, they did offer some protection for the assets of foreigners [20]. Over-time greater protections were 
included in these treaties, although they did not provide for direct dispute resolution by investors against host states. Foreign investors essentially had two options if their investment was somehow impaired by the host state. The doctrine governing international legal personality identifies states as the primary subjects of international law and generally does not allow an individual or corporation to take a legal action against a state [21]. As a consequence, foreign investors had to rely on diplomacy and political influence in order to persuade their home state to advance a legal claim on their behalf. The alternative was to initiate a claim in the national court of the host state under national law. Neither option proved to be satisfactory for the foreign investors; the first did not guarantee compensation, while the second rarely resulted in their success ([19], p. 781). Nor did the rules of customary international law provide for the right of a foreign investor to make monetary transfers from the host state or to bring in personnel to operate their investments, while the standards governing compensation were ill-defined [22].

After World War II the United States began incorporating investment protections into its FCN treaties. The United States supported what was known as the "Hull Rule", articulated by American Secretary of State, Cordell Hull, in a note to the Mexican Minister of Foreign Affairs, concerning compensation due upon the Mexican expropriation of foreign-owned agrarian and oil properties. The Hull Rule describes the standard of compensation due under customary international law as "prompt, adequate, and effective" compensation. However, while supported by the developed world, this rule was challenged in the post World War II period by developing countries who were emerging as independent states during decolonization. The wave of nationalizations and expropriations (direct takings) without compensation that took place during this time led to the erosion of the rule as a principle of customary international law. Mexico rejected the rule, as too did the Soviet Union and other Latin American countries. These states engaged in massive expropriations without compensation. Jeswald Salacuse observes that the average number of nationalizations of foreign investor property rose steadily from about fifteen per year in 1960 to over fifty a year in 1975 ([2], p. 435, note 42).

During this time the United Nations General Assembly (UNGA) was the focus of developing countries claims for a New International Economic Order. The 1962 UNGA Resolution on Permanent Sovereignty Over Natural Resources articulated the standard of compensation as appropriate compensation in accord with the laws of the host state and by the mid 1970s the rule had ceased to have the status of customary international law ([23], p. 641). This left the law governing foreign investment uncertain, with capital exporting states advancing the Hull Rule, and capital importing states rejecting it in a standoff.

International investment agreements emerged as the solution to this uncertainty in the late 1960s, although the first BIT was entered into before this in 1959 between West Germany and Pakistan and later Japan in 1977, and the United States in 1982 ([23], p. 653). They are "based on the presumption that the guarantees provided to foreign investors by the domestic legal system of the host country may be-or may turn out to be-insufficient for the special purpose intended by those treaties, which is primarily the creation of an investment climate designed to attract the foreign investment desired by the host state" ([24], p. 954).

The International Centre for the Settlement of Investment Disputes (ICSID) was created in 1966 under the auspices of the World Bank to provide investors with the institutional framework for taking direct legal action under a BIT against host states. At first the developing countries were unwilling to use it and ICSID only heard its first case in 1972 ([2], p. 439). However, the pace of BIT signing picked up and saw vast expansion by the 1990s, leading to today's situation where investor-state arbitrations occur regularly under the auspices of ICSID and NAFTA Chapter 11.

The development of this investor-state regime and the steady global expansion of international investment agreements are thus due to a number of geopolitical, economic, institutional, and ideological developments [25]. But how do these agreements function and why do they form an essential part of the emerging private transnational regulatory order?

As noted earlier, BITs provide direct legal access for foreign investors against host states without having to go to national courts, bypassing the exhaustion of local remedies. In providing for investor-state arbitration BITs give "private persons and companies the right to compel a sovereign state to appear before a tribunal and defend its sovereign actions ostensibly taken to protect the public interest" ([2], p. 460). This has been described as a "revolutionary innovation" that has caused a "paradigm shift" in and "profound transformation" of international law, which was unprecedented ([26], p. 46, note 175). Even in the World Trade Organization (WTO), which possesses one of the most developed dispute settlement systems, private actors do not have legal standingonly states may bring actions. Salacuse notes of these important developments:

Thus the global investment regime has granted a private right of action to investors. It has thereby privatized the decision-making process to a large extent. Not only are private parties involved as litigants, but also as arbitrators-the decision makers in the process-who are private persons compensated by the disputants, not officials of governments or international organizations ([2], p. 460). 
But, in addition to the privatization of dispute resolution under investor-state proceedings, the process has been transnationalized by significantly delocalizing and denationalizing its institutional context, procedures, and substantive law. The now classic definition of transnational relations articulated by Robert Keohane and Joseph Nye is "regular interactions across national boundaries when at least one actor is a non-state actor" ([27], pp. xii-xvi). While influential, this definition of transnationalism obscures the important insight that the transnational is not a territorially defined physical space existing at some level above the state, but is constituted within states where legislation, such as that implementing the New York Convention on the Enforcement of Foreign Arbitral Awards, legislation limiting national judicial review of foreign arbitral awards, or legislation and policies permitting the waiver of the exhaustion of local remedies rule, enable private actors to operate in a deterritorialized and denationalized legal space. I have elsewhere argued that the transnational is, ontologically and epistemologically, not a level of analysis, distinct from the national or domestic levels, but rather "extends across and thereby links as well as transcends, different (territorial) levels" [28]. Moreover, it links local and global orders through privatized processes of dispute resolution. Alec Sweet Stone goes to great lengths to emphasize the fundamental difference between the transnational investment regime as fundamentally distinct as a "private transnational space" from that of the European Union, which he characterizes as a "public supranational space" constructed by states ([29], p. 628).

Importantly, most BITs provide general consent to delocalized, binding arbitration, unlike specific consent in a contract to arbitrate where the parties will be governed by the domestic rules of contract under the applicable system of private international law/conflicts of law. Gus Van Harten [9] identifies three ways in which a state may consent to the compulsory arbitration of future investment disputes: by contract with an investor containing a binding arbitration clause; by legislation that provides for compulsory arbitration of investment disputes within a state's territory; and by treaty providing for compulsory investor-state arbitration. The latter two provide general consent, while the first provides specific consent to disputes arising out of the contract.

The notion of general consent signaled a profound shift in the nature and consequences of investorstate arbitration. A general consent by the host state allows investors to initiate compulsory arbitration of an investment dispute in the absence of a contractual relationship between the investor and the state. Thus disputes about the regulatory authority of the state are brought within the jurisdiction of international arbitration tribunals. Policy questions regarding the exercise of govern- mental powers are resolved, at the instance of the investors, by private arbitrators whose decisions are insulated from review by public courts (whether domestic or international). In this way, the general consent to investor-state arbitration is the conception of the system of investor protection as an instrument of transnational governance ([9], p. 607).

The general consent given by a host state "is general because it authorizes the arbitration of any future dispute with any foreign investor [of the state party] in the states territory" ([9], p. 607). In this way a general consent in an investment agreement operates like "blank cheque which may be cashed for an unknown amount at a future and as yet unknown date" ([9], p. 607). In so doing it "transforms investor-state arbitration from a modified form of commercial arbitration into a system to control the states exercise of regulatory authority with respect to investors as a group" ([9], p. 608).

The requirement to exhaust local remedies is a traditional rule of international law and requires that a natural or legal person must first have recourse to all means of redress available in the domestic law of the host state before bringing a claim against that state in an international forum. However, for ICSID proceedings states agree in advance on the basis of provisions of the ICSID Convention to refrain from requesting that local remedies be pursued for investment arbitrations arising out of leases, concessions or other contracts governed by the investment treaty. In return the home start agrees not to grant diplomatic protection of its nationals. This in effect suspends the operation of local laws and "lifts individuals onto the international plane vis-à-vis the host state" ([24], p. 957). The UNCITRAL Arbitration Rules are silent on the matter.

BITs differ in their treatment of the exhaustion of local remedies rule: only a few BITs concluded since 1985 provide for the application of the rule prior to arbitration under the BIT ([30], p. 50). Jan Paulsson notes that some BITs contain the requirement to exhaust local remedies for a period of time, while others do not, indirectly waiving the requirement ([31], p. 240). Romanian BITs typically articulate the rule, as too does the Germany-Israel BIT, whereas the Australia-Czechoslovakia BIT states that local remedies need not be exhausted. Some BITs provide for arbitration if the dispute has not been settled through local means after a certain amount of time, as in the Argentina-German BIT. Also, some BITs articulate a fork in the road provision whereby once a particular dispute settlement route has been chose it forecloses electing another route, reflecting the Latin maxim via electa non datur recursus as alteram: "Once a road is chosen, there is no recourse to the other" ([30], p. 51). A study of 148 German BITs reveals that the majority explicitly waive the local remedies rule, many do not even raise it, and only three require the exhaustion of 
local remedies ([30], p. 52). From 2000 onward Germany, who has the highest number of BITs in force, has explicitly waived the rule in German BITs [30].

The general consent feature of an investment treaty thus "exposes a state to a broad range of claims by a foreign investor related to the states exercise of public authority. These investment treaties, which initially were aimed at reducing an investor's risk of investing abroad, have now been transformed into tools with which to assail an extensive range of host states governmental activity" ([19], p. 782).

An investment agreement will generally contain three elements: definitions, substantive obligations for host states, and provisions for binding investor-state dispute resolution. Breaches of BITs constitute breaches of international law and the protections for investors are much stronger and broader than those under the Hull Rule. Whereas the Hull Rule mainly addressed direct expropriations, today it is takings, short of expropriation that most often engage arbitrators ([23], p. 644). "Investment" is defined in most treaties, such as the Model US BIT, to include a broad range of agreements as investment and thus governed by the BIT. A broadly defined BIT can bring under its jurisdiction many types of contracts and subject them to delocalized arbitration even when the terms are silent on the matter ([32], p. 76). Also "umbrella clauses" may be used which create the possibility of bringing all contractual arrangements the state may enter into with the foreign investor under the investment treaty, thereby transforming the breach of any contract entered into between the state and investor into a breach of their BIT. There is considerable doctrinal and jurisprudential debate over the operation of these clauses, which has been described as one of the most contentious issues of international investment law ([33], p. 5). They are regarded as reflecting the desire to delocalize the law applying to international contracts:

The emergence of the clause in modern investment protection treaties must be seen in the broader context of efforts to internationalize the legal framework applicable to international concession contracts. Whereas many capital importing countries used to emphasize the exclusive applicability of their domestic legislation to concession contracts concluded with foreign investors, various efforts have been made to withdraw these contracts from the unilateral regulatory power of the host state ([24], p. 965).

However, Rudolf Dolzer also notes that the internationalization and delocalization of a contract by a BIT is complicated and depends on the nature of the breach as a contract breach or a treaty breach, as well as whether the contract provides for exclusive national court jurisdiction for breach of contract. The first case to consider this was Lanco International Inc. $v$. The Argentine Republic [34]. There an ICSID arbitration tribunal held that consent to arbitration under the BIT prevailed over a provision in the concession contract for the submission of disputes to local courts. Andrew Guzman argues that "by making any breach of an agreement a violation of an international treaty...BITs allow such agreements to be treated as contracts between private parties..." ([23], p. 655), internationalizing the contract. However, Francisco Vicuña rejects that the internationalization of a contract turns it into a treaty-it just brings treaties and contracts into a closer nexus and subjects the latter to international law: "treaties and contracts, albeit different, pursue the same objective of ensuring the rule of law and the observance of legal commitments in the international community and are thus called to increasing interaction. To this end, treaties are becoming privatized by allowing a greater role for individuals in their operation, just as contracts are becoming public to the extent that states and international law extend their guarantees to their observance. All of it points towards the need for global protection in a global society, where perhaps the distinction between public and private law will become less meaningful" ([35], p. 357).

In addition to providing definitions of investment, the typical BIT will establish general standards of behavior of the host state. The common standards include "fair and equitable treatment", "full protection and security", "national treatment", "most-favorednation treatment", and "treatment in accordance with international law". The BIT will also include specific standards concerning the investment, such as dealing with monetary transfers, expropriation, investor rights during war, revolution or civil unrest. The BIT rarely states specific consequences of a breach, but arbitration tribunals have held uniformly that compensation is due upon breaches resulting in injury on the basis of customary international law ([2], p. 446).

Finally, the BIT will provide for a binding enforcement mechanism for investors and will often designate the arbitration institutions and rules to be adopted. Andrew Guzman observes that "BITs offer foreign investors greater protection than the Hull Rule ever did...by providing a mechanism through which a potential investor and a potential host can establish a contract that is binding under international law" ([23], p. 658), which was not possible under customary international law. Absent a BIT, a state is not able to credibly bind itself to an investor: domestic law is not a credible option as the laws may be changed and there is no guarantee of a fair hearing, while there are virtually no mechanisms for securing contractual promises between a state and private firm under international law, as noted earlier. Binding dispute resolution through international arbitration thus allows foreign investors to sue host states directly if they believe that the investment agreement governing their investment has been violated. BITs thus revolutionize contractual enforcement. In fact, investor-state 
arbitration is described by Jan Paulsson as "not a subgenre of an existing discipline. It is dramatically different from anything previously known in the international sphere" ([31], p. 256). Another notes that this delocalization produces a democratic deficit:

State parties to investment agreements can no longer legislate at will in the public interest without concern that an arbitral tribunal will determine that the legislation constitutes interference with an investment. Thus investment arbitration may result in an overall loss of state independence and sovereignty, which has implications for democratic governance (...) The question arises whether state exercises of public authority should be adjudicated by foreigners, largely on the basis of commercial principles, when the adjudicators are unconcerned with the wider effects of their decisions ([19], p. 799).

Investor-state arbitral proceedings differ so fundamentally from adjudication in courts of law that many question the formers adequacy in settling disputes that raise public interest issues. Questions concerning the independence and impartiality of private arbitrators, limited public access to the arbitral documents, proceedings, and awards, the absence of appeal mechanisms, and the application of private commercial law standards and conceptions to public law issues are some of the more serious defects in process that invite criticisms of the democratic deficit and undemocratic supremacy of governance through arbitration $[18,19]$.

Specialists note an epistemological divide between international commercial lawyers and public international lawyers that creates conflicting approaches to investor-state arbitration. "Even though public and private law perspectives mostly merge in investment treaty arbitrations, there remains a divide in the conceptual frameworks of the private and public law perspectives and in the epistemic communities of commercial arbitration and public international lawyers" ([36], p. 10). Moreover, regulatory competition amongst states for foreign investment in the 1980 s and 1990s resulted in the legislation of limits on judicial interference with foreign arbitral awards by many states. Belgium in 1985 removed any oversight of foreign awards by Belgian courts and has been criticized for bowing to competitive pressures to become more attractive investment site ([9], p. 617). Competitive pressures have also generated forum shopping by investors for the states that offer the most attractive investment regimes. This is said to contribute to governance gaps, as noted by John Ruggie, former Special Representative of the UN Secretary General on the issue of human rights and transnational corporations:

Investor protections have expanded with little regard to States duties to protect, skewing the balance between the two. Consequently, host states can find it difficult to strengthen domestic social and environmental standards, including those related to human rights, without fear of foreigninvestor challenge, which can take place under binding international arbitration ([37], p. 29).

Indeed, while this section has reviewed the history of the investor protection regime and the emergence of investment treaties as central institutions in providing for the stability of investment relations, it notes that these agreements also raise concerns about their impact on state autonomy and the broader democratic legitimacy of the investor-state legal regime. Indeed, Stephan Schill argues that clauses that limit state legislative and policy autonomy, like umbrella and stabilization clauses, function to privately order investor-state relations precisely by preventing states from pursuing opportunistic behaviour that might present itself over the course of a long-term contract [33]. These clauses highlight the tensions between the investors' interest in securing investment against future political risks and the host states interest in ensuring adequate policy autonomy in the face of changing circumstances or unanticipated developments not addressed in the agreements. Such concerns have led some to question why states would agree to bind their legislative and policy independence into the future. The following section will examine this question and will consider the insights afforded by theories of incomplete contracts into the political economy of investment agreements. It argues that although governance through BITs raises significant governance gaps, BITs also create distinctive political economies that have implications for the advancement of development and human rights.

\section{The Political Economy of Investment Agree- ments and Contract Theory}

The President of Bolivia once stated that in investorstate arbitrations Latin American developing countries "never win the cases. The transnationals always win" ([38], p. 436). In a review of allegations of the systemic bias of the arbitral system against developing countries, Susan Franck notes that Nicaragua promotes withdrawal from ICSID, while Ecuador is eliminating investment arbitration ([38], pp. 436437). Venezuela has renounced the ICSID Convention [39]. These developments are not surprising, given the well-known fact that the system is a product of an alliance between a multinational investment lobby and central capital exporting states and is clearly weighted in favour of investor protection. ICSID is a creation of the World Bank whose weighted voting system favours powerful developed states. The investor-state regime allocates power between foreign investors and the host state, creating political economies that result in significant distributional outcomes. A number of people have identified a paradox for developing countries at the heart of the system. Salacuse asks: 
"why do developing countries, who usually have few national investors in need of protection abroad, sign investment treaties whose effect is to restrain their own governments in their dealings with foreign investors?" ([2], p. 440). Note that BITs do not impose duties on foreign investors and nor do they give the host state the capacity to sue the foreign investor ([40], p. 499). While the ICSID Convention has given rise to a few claims made by states, they are regarded as anomalous ([41], p. 101). Indeed, the lopsided nature of the investor protection regime has prompted some to conclude that it distorts the balance between public and private authority:

\section{(...) the one-sided nature of the dispute settlement system, in which only private investors may initiate a claim and only states must pay damages, privileges private property and contract rights over the public interest. It creates a system of third- party beneficiaries, making the regime more rigid. It promotes private rights and relegates states to defensive status. BITs thus collapse the public/ private binary and shift the boundary between the public good and private interests by privatizing part of the public. This re-conceptualization limits the influence of public concepts traditionally considered part of the state such as human rights, the environment, and democracy ([40], p. 519).}

The proliferation of BITs entered into by developing states that provide much greater protection for foreign investors than the Hull Rule ever did appear to be incongruous, if not contradictory with their earlier rejection of the Hull Rule. Some suggest that developing countries may in fact be better off under customary international law than under BITs ([42], p. 615). M. Sornarajah ([43], p. 259; [44], p. 90) refers to this contradiction as "duplicitous", while Guzman poses the question even more provocatively, in a paper entitled "Why LDCs Sign Treaties That Hurt Them" [23].

Various international relations and political economy theories may be advanced to explain the position adopted by developing countries and to account for the nature and operation of the investorstate regime. Hegemonic stability theory draws on neorealist theories and posits that international regimes will arise when they are promoted and enforced by a powerful state. However, this theory clearly provides a blunt analytical instrument for no single hegemonic state has advanced the investorstate regime and it does not explain why developing countries would join, despite their rejection of Hull Rule ([2], p. 433). Theories of international cooperation and international contracting based upon liberal foundations in rational choice theory, transactioncoast analysis, and theories of collective goods provide some insight [45]. They suggest that the regime advances the interests of all parties by reducing the relative costs of investing-capitalexporting states reduce their enforcement costs and the risk of default (expropriation, etc.). Capitalimporting states wish to attract foreign investment and so enter into agreements to reduce the perceived risk of default and to enhance their competitive edge against other capital-importing states.

In fact, BITs have been described as "quintessentially liberal documents. The typical BIT cites two goals in its preamble: the creation of favorable conditions for investment by nationals and companies of one party in the territory of the other, and increased prosperity in both states" ([46], p. 627). While challenged by economic nationalists and Marxists, who regard foreign investment agreements to be overwhelmingly of disproportionate and declining benefit over-time to the foreign investor, liberal analysts argue that the parties gain mutually (but not necessarily equally) under investment agreements when they are based upon the comparative advantages of the parties ([46], p. 624). According to liberal theory, BITs thus operate to protect the investment from state interference, to "insulate the market from politics", and to encourage foreign investment in the host state, who limits its role to "protecting private rights of property and contract", thereby producing efficient exchange ([46], pp. 623-624; see $[47,48])$.

As Elkins, Guzman and Simmons find, "the proliferation of BITs-and the liberal property rights regime they embody-is propelled in good part by the competition among potential host countries for credible property rights protections that direct investors require" ([49], p. 812). But we know that BITs are tilted in favour of the capital-exporter and do not benefit all parties equally, so this still does not address the paradox of why the capital-importer would agree to a one-sided bargain.

The theory of limited contracting provides useful insight into the political economy of BITs. "Contract theory is primarily an analytical approach to explain why parties enter into contracts in the first place and why they write the contracts that they do, in light of what courts do. It also helps to answer questions of optimal contracting" ([50], p. 515). Liberal economic theory of contract assumes that parties to a contract act rationally and desire to enter into agreements that optimize their benefits both at the time of contracting and in the future. However, the future poses problems of uncertainty that can affect the distribution of benefits under the contract ([51], p. 280). Inspired by the work of Oliver Wiliamson [52], limited contract theory analyzes the power structure of contractual relationships. Incomplete contracts are forms of relational contracting where the contract operates over a period of time and incompletely specifies the performance obligations. They are contrasted with discrete contracts, the latter being fully specified ([48], pp. 140-141). The theory of limited contract suggests that over time in situations of asset specificity there will be an incentive for one of the parties to delay or in some way hold up performance 
under the contract. As Robert Scott puts it, "the investing party (...) risks being held up by a promisor (...) who can renege on his promise and force a renegotiation of the contract. This threat will be credible if the (...) investment cannot be used for other purposes outside the relationship (...) [T]he sunk costs will increase the risk that the Buyer will threaten to walk away from the deal unless the Seller [investor] agrees to renegotiate the initial contract terms" ([51], p. 284).

When applied to international relations, incomplete contracting theory identifies a paradox that bears some likeness to the paradox identified in this paper concerning the entry of developing countries into investment agreements that impose far greater limits on their sovereignty than those imposed by the Hull Rule. States highly desire to protect their sovereignty, but regularly enter into agreements that limit it, such as the Treaty of Rome that created the EEC [53]. This seems at odds with the general anarchic character of international relations and uncertainty about the longterm implications and distributional consequences of agreements limiting their sovereignty. The absence of some sort of centralized enforcement mechanism to ensure that the parties honour their commitments also suggests that states will avoid such arrangements. However, BITs have proliferated in both the developed and developing worlds.

(...) incomplete contracting theory can clarify how and why states choose to bundle and unbundle their sovereignty, what the dynamics will likely be of future renegotiation, why some of these incomplete contracts might unravel (...) Theories of incomplete contracting are particularly instructive for explaining the organizational boundaries of the international system (...) The lack of a central governing authority ensures that states must be wary of the long-term distributional consequences of their actions and be hesitant to commit to longterm agreements (...) In such an environment incomplete contracts offer two important advantages for states. First, incomplete contracts delineate general principles and broad goals to which states can aspire (...) Second, contractual renegotiation acts as an important institutional check on the future behavior of actors (...) Incomplete contracts also offer added flexibility to correct for distributional asymmetries that may arise as the result of the initial agreement. In short, incomplete contracts between states are framework agreements that do not fully apportion sovereignty. Instead such agreements make the distribution and allocation of sovereign rights a matter of on-going negotiation between the contracting parties or between those parties and a third party, such as a supranational organization ([53], pp. 5-6).

Incomplete contracts are used by states in condi- tions involving variety of uncertainties and transactions costs that prevent states from entering into fully specified agreements. There are procedural reasons arising from uncertainty costs (inability of states to anticipate all future contingencies), negotiating costs (information limitations that prevent the negotiation of optimal agreements), and enforcement costs (inability to negotiate an enforcement mechanism). There are also strategic reasons for negotiating incomplete contracts. In cases where the contract governs specific assets and the transactions are frequent the owner of the assets will have strategic reasons in order to extract more benefits under the agreement later in time. As Cooley and Spruyt note "[i]n certain cases of incomplete contracting, such as contracting over natural resource use, the host country tends to gain more leverage as the foreign country (investor) sinks more transaction-specific assets into such exploitation" ([53], p. 11).

Drawing an analogy between an investment agreement as an incomplete contract, we may analyze BITs as incomplete contracts between states [54]. Indeed, Anne van Aaken argues that BITs "may be interpreted as mechanisms to overcome commitment problems between investor and host state in order to generate mutual benefits. A state thereby promises not to infringe on the property rights of foreign direct investors so as to attract more investment" ([50], p. 509). She suggests that in terms of law, BITs may be conceptualized as contracts in favour of third parties ([50], p. 520). Host states thus trade off some sovereignty for credibility by restricting their regulatory capacities and agreeing to submit to compulsory binding arbitration. In the case of the BIT, sovereignty is apportioned between the host state, the foreign investor, and the designated binding arbitration tribunal. The challenge, however, is for the parties to strike the right balance between commitment and flexibility-too much commitment can reduce flexibility and the ability to adjust to changing circumstances that alter the distribution of the benefits and costs of the agreement.

As mentioned already, incomplete contracting theory indicates that the incentive structure and distribution of benefits changes over the course of a contractual relationship. Incomplete contracts "alter the relative bargaining positions and change the distribution of benefits to contracting parties over time" and importantly, "the holder of residual rights of control will be able to determine the future allocation of sovereign rights that were not covered in the initial agreement" ([53], p. 11). Guzman argues that while BITs may reduce the overall welfare of developing states, the competitive pressures to attract foreign investment create an incentive structure that encourages the negotiation of significant concessions to foreign investors at the onset of the relationship [23]. The absence of a credible contracting mechanism dictates that host states agree to binding dispute settlement and the various standards that are common- 
place in the usual BIT. At this point the foreign investor is in the driver's seat. However, once the investment is made, the host state no longer has to offer incentives to attract new investment, but now is concerned about keeping the existing investment. At this point the host gains power in the relationship and is in a position to extract benefits from the foreign investor through tax increases or other policy measures.

Raymond Vernon describes the plight of the foreign investor as an "obsolescing bargain" because of the decline in the bargaining power of the foreign investor during the course of the investment ([55], p. 46). Once the investment has been made the investor cannot easily move its assets without incurring major costs. For these reasons parties often include renegotiation and stabilization clauses, but these clearly open the relationship up to conflicts of interest between the host state and the foreign investor. Incomplete contracting theory also suggests that an important variable in determining who holds power in a contractual relationship is the party who retains ownership rights in the residual assets. Drawing on the work of Oliver Hart [56], David Lake addresses the power significance of the "locus of rights of residual control":

(...) contracts vary in both their specificity and the rights of residual control possessed by each member; indeed, the latter is the defining attribute of relational hierarchy (...) In constructing contracts, states are defining the terms of their transactions; the potential for cheating, defection, and other forms of opportunism; and the means for controlling one anothers behavior. In this approach, contracts are instruments through which to control the behavior of others ([57], p. 10).

Host states, by retaining residual property rights in the investment are, in theory, able to exert pressure on the foreign investor to extract further benefits under the BIT. However, BITs also provide for compulsory binding arbitration, suggesting that residual rights have been transferred, at least in some measure, to a third party [58]. Thus the ability of the host state to hold up the agreement might be limited in important ways by the outcome of arbitral proceedings. Tribunals differ in the strictness in which they interpret the provisions of BITs, with ICSID being known for strict interpretations ([50], p. 528). However, other tribunals can be more generous in their interpretation of substantive BIT provisions. Thus third party involvement inserts further uncertainty into the agreement and might well open up a governance gap that functions as a window of opportunity for the advancement of extra-contractual objectives in the investment relationship, such as the promotion of human rights. To what extent can BITs create opportunities for the advancement of human rights?

\section{BITs and the Advancement of Human Rights}

Human rights may enter into the investor-state relationship in a variety of ways. They may be raised by the foreign investor in a claim or as a defence to a claim under a BIT. They may also be put in issue by the host state or utilized by arbitrators as construction aids in interpreting the provisions of a BIT. Finally, human rights may be expressly incorporated into a BIT. Each will be considered in turn.

Corporations and individual investors are entitled to human rights protections under a number of regional and international human rights treaties. Specifically, the protections afforded by the European Convention on Human Rights in cases taken before the European Court of Human Rights has been a significant venue for investor claims, in addition to claims being made before arbitrations under the relevant BITs ([59], p. 23, note 44). Arbitrators have looked to the jurisprudence of the European Court of Human Rights Human Rights in Mondev v. United States [60], a NAFTA Chapter 11 claim by a Canadian investor against the United States Government to the effect that the US courts had violated his rights under international law. The Tribunal held that decisions from the European Court "provide guidance by analogy" concerning the scope of NAFTA's guarantee of "treatment in accordance with international law, including fair and equitable treatment and full protection and security" ([60], para. 144). In Tecmed $v$. Mexico [61], a case involving a Mexican refusal to renew a permit to operate a landfill site near an urban centre, precipitated by local opposition for environmental and health reasons, arbitrators also consulted European Court of Human Rights jurisprudence in interpreting the host states duties under the BIT with respect to expropriations and nationalization. This approach was later followed by an ICSID tribunal in Azurix $v$. Argentina dealing with the interpretation of an expropriation clause in the US-Argentina BIT ([62], paras. 311-312). The Tribunal agreed that the European Court of Human Rights provided "useful guidance" in interpreting the BIT.

In Glamis Gold Ltd. v. United States of America [63] Glamis Gold Ltd., a publicly-held Canadian corporation engaged in the mining of precious metals, submitted a NAFTA claim to arbitration under the UNCITRAL Arbitration Rules on behalf of its enterprises Glamis Gold, Inc. and Glamis Imperial Corporation for alleged injuries relating to a proposed gold mine in Imperial County, California. Glamis claimed that certain federal government actions and California measures with respect to open-pit mining operations resulted in the expropriation of its investments and denied its investments the minimum standard of treatment under international law. The California measures included regulations requiring backfilling and grading for mining operations in the 
vicinity of Native American sacred sites. Glamis claimed damages of not less than $\$ 50$ million. The Tribunal released the Award, dismissing Glamiss claim in its entirety and ordering Glamis to pay two-thirds of the arbitration costs in the case.

In this case, the Quechan Indian Nation submitted an amicus curiae brief arguing that the NAFTA provisions should be interpreted in a manner consistent with US obligations in treaty and customary law to protect indigenous peoples' land and resources. In general, the award contains many references to the Quechan Nation, particularly during the course of the factual overview, which details their involvement in various environmental and cultural impact assessments. The backfilling and grading requirements were imposed by the state as an attempt to strike a balance between the need to protect adjacent Quechan sacred sites without imposing an outright ban on mining, or even more excessive costs on Glamis. The tribunal held that the economic impact of the state's measures were not sufficient to effect expropriation of Glamiss investment. The respondent did not choose to incorporate into its defence the arguments made in the amicus curiae brief of the Quechan Indian Nation. As a result, there is no reference to human rights claims or their incorporation into the concept of fair and equitable treatment, either in the respondents arguments or in the tribunals analysis.

In Grand River Enterprises Six Nations, Ltd., et al. $v$. United States of America [64] the company comprised by Canadian First Nations individuals engaged in the manufacture and export of tobacco products to the United States made a claim under the investor-state provision of NAFTA, Chapter 11 against the United States Government. The claimants argued that the government had violated the national treatment and most favoured nation treatment provisions, as well as customary international legal standards of fair and equitable treatment, and full protection and security, which resulted in an expropriation of their investment. The claimants invoked the UN Declaration on the Rights of Indigenous Peoples, customary international law, and the jurisprudence of the Inter-American Court of Human Rights in advancing their claim that indigenous rights should be taken into special consideration in a NAFTA Arbitration. In a restrained decision the Tribunal found that while there may be a principle of customary international law concerning fair and equitable treatment that requires special consultation with indigenous peoples when their rights are affected, it was not applicable to an individual investor ([63], para. 213).

In terms of the host state raising human rights claims, there are a number of BIT arbitrations involving claims by host states of breaches of the human right to water [65]. Many of these cases were brought against Argentina, while a few involved Bolivia and Tunisia. In each case, the state was engaged in water sector privatization schemes and the granting of concessions to foreign water corporations. In Suez, Sociedad General de Aguas de Barcelona S.A. and Vivendi Universal S.A v. Argentine Republic [66] investors were claiming in an ICSID arbitration a breach of a number of BITs that Argentina had entered into with their home countries. The case involved a thirty year contract to manage a water and sewage concession. Over the course of the relationship a number of disputes arose and with the intensification of the Argentine financial crisis the parties were at odds over the tariff-rates charged to consumers and the investors wanted to modify the rates under the economic equilibrium clause in the concession agreement. However, Argentina resisted. The human right to water was invoked by Argentina as one argument in its defence of necessity to its termination of the water concession, supported by an amicus curiae submission filed by five NGOs (this case is the first under ICSID in which such submissions were accepted in spite of the objections of one of the parties). In general, the tribunal emphasized the "defenses exceptional nature" and the strict conditions surrounding its application ([66], para. 258) and rejected Argentina's defence because Argentina's measures in violation of the BITs were not the only means to satisfy its essential interests and "because Argentina itself contributed to the emergency situation that it was facing in 2001-2003" ([66], para. 265).

The tribunal's evaluation of the human right to water argument is relatively brief (quoted in toto below) and occurs within its consideration of the third condition for the defence of necessity, that the treaty obligation does not exclude the necessity defence, a condition Argentina was held to have met. Nevertheless, it emphasized that Argentina's obligations to uphold human rights were in addition to their obligation to uphold their investment treaty commitments and did not relieve them from those obligations:

Argentina and the amicus curiae submissions received by the Tribunal suggest that Argentina's human rights obligations to assure its population the right to water somehow trumps its obligations under the BITs and that the existence of the human right to water also implicitly gives Argentina the authority to take actions in disregard of its BIT obligations. The Tribunal does not find a basis for such a conclusion either in the BITs or international law. Argentina is subject to both international obligations, i.e. human rights and treaty obligation, and must respect both of them equally. Under the circumstances of these cases, Argentina's human rights obligations and its investment treaty obligations are not inconsistent, contradictory, or mutually exclusive. Thus, as discussed above, Argentina could have respected both types of obligations ([66], para. 262).

Impregilo S.p.A. v. Argentine Republic [67] involved a factual background similar to the Suez case and was 
a dispute over Argentina's refusal to permit price increases in the context of currency devaluation brought about by the Argentine financial crisis and the state's eventual transfer of the water and sewage service back to a state-sponsored company. As in the Suez case, Argentina invoked the defence of necessity based in part on its obligation to fulfil the human right to water.

The human right to water, even though raised by Argentina, was only indirectly addressed in the majority's decision. The tribunal held that the state's obligations to provide water were encompassed by the definition of an essential interest which a defendant must prove has been imperilled in claiming the defence of necessity:

$[T]$ he term 'essential interest' can encompass not only the existence and independence of a State itself, but also other subsidiary but nonetheless essential interests, such as the preservation of the States broader social, economic and environmental stability, and its ability to provide for the fundamental needs of its population. It follows that, in addition to Argentina's overall stability, the need to provide the population with water and sewage facilities represented an 'essential interest' which, in regard to thousands of people, was to be served by AGBAs concession and which would allegedly be imperiled for them but for the acts of the Argentine authorities ([67], para. 346).

Although the tribunal found that there was a grave and imminent peril to the essential interest of Argentina's economic stability, it ultimately held that Argentina contributed to the crisis and thus was not successful in invoking the necessity plea, with no further reference to the human right to water.

These cases do not exactly indicate the robust influence of human rights laws on arbitration proceedings. Rather, the tribunals seem to be very cautious in elevating human rights laws to the same status of investment protections. Arguably the number of cases reviewed is too small to draw meaningful conclusions about a tribunal's potential influence over the power residing with residual ownership. In some cases the investor won and in some the host state won.

However, these cases do raise the important issue of the propriety of addressing human rights in the context of investment arbitration [68]. It is highly likely that arbitrators trained in international commercial law and most often acting for private parties are neither willing nor competent to engage in the construction and interpretation of human rights. To what extent would the situation change if human rights protections were to be incorporated expressly into the BIT? Can governance gaps be filled in by human rights? This is the position taken by John Ruggie, former Special Representative of the UN on Business and Human Rights, in the Guiding principles:
States should maintain adequate domestic policy space to meet their human rights obligations when pursuing business-related policy objectives with other States or business enterprises, for instance through investment treaties or contracts (...) Economic agreements concluded by States, either with other States or with business enterprisessuch as bilateral investment treaties, free-trade agreements or contracts for investment projectscreate economic opportunities for States. But they can also affect the domestic policy space of governments. For example, the terms of international investment agreements may constrain States from fully implementing new human rights legislation or put them at risk of binding arbitration if they do so. Therefore, States should ensure that they retain adequate policy and regulatory ability to protect human rights under the terms of such agreements, while providing the necessary investor protection ([37], p. 12).

The Guiding Principles on Business and Human Rights advanced by John Ruggie carefully differentiate between the legal duties held by states to protect human rights and the social responsibilities of business corporations to respect human rights. The distinction between legal duties and social responsibilities, of course, reflects the operation of the doctrine governing international legal personality and the limited persona of private business corporations under international law, discussed earlier.

While, International Chamber of Commerce opposes the inclusion of labour or environmental standards into BITs, and few BITs mention human rights save perhaps in general terms in the preamble, as does the Dutch Model BIT, some model BITs are moving in this direction ([9], p. 614). Canada developed a new model Foreign Investment Protection Agreement (FIPA), the Canadian equivalent of a BIT. The model FIPA embodies changes resulting from controversial experiences arbitrating under NAFTA Chapter 11 investor-state provision. Controversy over Chapter 11 arbitrations stemmed from the criticisms advanced by environmental and civil society groups that investment commitments under NAFTA negatively impact on public policy in a number of areas and inhibit sustainable development. Concerns about the secrecy of the arbitral proceedings and lack of public access to information about investment disputes motivated a review of NAFTA arbitrations by the NAFTA Free Trade Commission which issued guidelines on the participation of non-disputing parties. As a result Canada and the United States agreed to open NAFTA arbitrations to the public and have recently made the draft negotiating texts of NAFTA publicly available. The new model treaty addresses many of the concerns expressed. The Canadian Model refers to sustainable development in the preamble and contains a GATT-like general exception that applies to all the 
obligations in the model treaty [69]. This exception covers measures adopted for the protection of human animal or plant life or health and conservation purposes. The Model also provides for public access to all documents and arbitral hearings are open to the public. In addition, it provides a procedure for nondisputing parties to file written submissions. The US Model BIT goes further and addresses relation between investment and labour rights.

Whether increasing the specificity of investment agreements, providing for public policy exceptions, and efforts to render arbitration processes more transparent and participatory will enhance or undermine the investor-state system is an open question, but one that has major implications for the future of governance through international investment agreements.

\section{The Legitimacy of Private Transnational Gov- ernance through BITs}

This paper has examined the centrality of the investor-state regime to the regulation of the global political economy, characterizing the regime as an instance of private transnational governance. The regime provides for a highly privatized system for binding dispute resolution that significantly delocalizes and denationalizes the laws and procedures governing dispute settlement. It provides foreign investors with an efficacious system that goes a long way to enhance certainty in international commercial contracting.

The analysis also explores the political economy of investment agreements and suggests that contract theory is analytically and theoretically able to tell us a considerable amount about governance through BITs. We have seen that international investment agreements function to create an institutional framework for investor-state relationships by providing for substantive standards of behaviour and compulsory dispute resolution that address credibility problems that plagued investment relations prior to the emergence of the investor-state regime. In addition, contract theory is useful in explaining the apparent paradox at the core of the regime concerning the asymmetric distribution of benefits under investment agreements. Incomplete contract theory indicates that the incentive structure and distribution of benefits changes over the course of the investment relationship, according more power over time to the host state as the owner of residual rights of control. At this point the host is in a position to extract benefits from the foreign investor through tax increases or other public policy measures that might open the door to advancing human rights concerns.

However, the analysis also suggests that contract theory and practice are uncertain in accounting for governance by means of BITs, particularly when the protection or advancement of human rights are at issue. Most BITs are silent on the broader regulatory and constitutional functions of investment agree- ments. Notwithstanding this silence, such concerns have entered into debate through the submissions of state parties to investment agreements and by the business corporations affected by the agreements. Human rights concerns have also been raised in the amicus curiae applications of non-parties and through the agency of arbitrators. However, arbitrators vary greatly in the strictness with which they interpret the provisions of BITs and the extent to which they are willing to consider the impact of investment agreements on human rights [50]. In addition to differences in interpretive strategies and cultures, as Van Aaken ([50], p. 528) notes, contract theory assumes disinterested third-party adjudication, but conflicts of interest and arbitrator bias are well-known problems in investment arbitration. This raises the important issue of the proper role of the arbitrator. Arguably, most arbitrators regard themselves as acting for the parties to resolve specific disputes and would consequently be reluctant to engage in significant public policy debates. Clearly, their competence and legitimacy in doing so are also at issue [70].

Critics of the investment arbitration regime identify a shrinking of domestic policy space, inflexibility of treaty obligations, lack of democratic accountability and pro-investment bias, secrecy and confidentiality of arbitral proceedings, conflicts of interest and arbitrator bias, forum shopping, and competitive pressures that produce a race-to-the bottom in standards [71]. Countries are beginning to defect from the regime. Bolivia was the first to reject the ICSID Convention in 2007, while Ecuador withdrew its consent to ICSID arbitrations for dispute dealing with oil and mining contracts and terminate a number of BITs [40]. Venezuela has denounced the ICSID Convention.

Pressure from civil society groups, including human rights and environmental organizations has resulted in significant changes in investor-state arbitration under NAFTA, while Norway has integrated corporate social responsibility and the protection of health, safety, the environment, labour, democracy and human rights into its Model BIT. Asha Kaushal submits that these are clarion calls to roll back the foreign investment regime. Countries and civil societies are calling for restraint of foreign property and contract rights in favour of national sovereignty ([40], p. 495). To add further fuel to the fire, there are studies suggesting that BITs do not necessarily encourage foreign investment or development $[40,72]$. Many believe that developing countries are bargaining away their sovereignty for uncertain gains ([40], p. 519).

In conclusion, governance through BITs has an uncertain capacity to advance human rights. Reordering the priority accorded to private and public interests in the investment relationship turns on the ability of states to reclaim the public space that has been traded off for the security of foreign investors. This requires states to take seriously their legal duties to protect human rights in investment relationships. 
Important, as well, is the balance that arbitrators are willing to strike between private or public politico-legal traditions in their decision-making. For the moment it might be that the most that can be hoped for from business corporations is the advancement of human rights through the gradual development of notions of corporate social responsibility in investor-state relations.

\section{References and Notes}

1. UNCTAD. World Investment Report 2010. Geneva, Switzerland: United Nations; 2010, p. 81. Available from: http://www.unctad.org/en/docs/wir20 10_en.pdf (accessed on 15 March 2012). The Netherlands has one of the largest networks in the world with some 98 agreements. See UNCTAD. Bilateral Investment Treaties Database. Available from: http://www.unctadxi.org/templates/DocSearch__ 77 9.aspx (accessed on 15 March 2012).

2. Salacuse J. The emerging global regime for investment. Harvard International Law Journal. 2010; 51(2):427-473.

3. Salacuse J. The treatification of International Investment Law. Law and Business Review of the Americas. 2007;13(1):155-166.

4. Cutler AC. Private power and global authority: Transnational merchant law in the global political economy. Cambridge, UK: Cambridge University Press; 2003.

5. Shapiro M. The globalization of freedom of contract. In: Shapiro M, Sweet AS, editors. On law, politics and judicialization. Oxford, UK: Oxford University Press; 2000.

6. Sweet AS. Islands of transnational governance. In: Shapiro M, Sweet AS, editors. On law, politics and judicialization. Oxford, UK: Oxford University Press; 2000.

7. Mattli W. Private justice in a global economy: From litigation to arbitration. International Organization. 2001;55(4):919-947.

8. Cutler AC. Transnational law and privatized governance. In: Pauly L, Coleman W, editors. Global ordering: Institutions and autonomy in a changing world. Vancouver and Toronto, Canada: UBC Press; 2008, pp. 144-163.

9. Van Harten G. Private authority and transnational governance: The contours of the international system of investor protection. Review of International Political Economy. 2005;12(4):600-623. Although Van Harten argues that investment treaty arbitration does not regulate the conduct of private parties, this paper argues that regulating the behavior of states toward foreign investment necessarily affects the rights and duties of private parties. However, there is disagreement over whether investment treaties grant investors procedural rights, substantive rights or mere benefits. One view, informed by traditional principles of public international law regards the investor as holding

\section{Acknowledgements}

The author would like to thank the Hague Institute for the Internationalisation of Law (HiiL) for its generous support in completing the research informing this paper during her tenure as the Morris Tabaksblat Visiting Chair on Private Actors and Globalisation.

derivative rights, delegated to them by their state. See The Loewen Group Inc. v. United States, ICSID, Case No. ARB(AF)/98/3, para 3, 2003, which held that claimants are permitted for convenience to enforce what are in origin the rights of party states. The alternate view is rooted in contract law terms and regards investors as third party beneficiaries under the BIT. See Occidental Exploration and Production Co. v. Republic of Ecuador, [2005] EWCA (Civ) 1116, para. 20; [2005] 2 Q.B. 432, 450 (C.A.), where the English Court of Appeal held that the fundamental assumption underlying the investment treaty regime is clearly that the investor is bringing a cause of action based upon the vindication of its own rights rather than those of its national State. See also Douglas Z. The hybrid foundations of investment treaty arbitration. British Yearbook of International Law. 2003; 74(1):151-289.

10. See Browne M, Coon J. The impact of market ideology on transnational contract law. Loyola of Los Angeles International and Comparative Law Review. 2008;30(2):91-110 for an informative analysis of the foundation of transnational contract law in classical eighteenth and nineteenth century liberal conceptions of individual responsibility, laissez-faireism, and universality.

11. See May $C$. The rule of law as the grundnorm of the new constitutionalism. In: Gill S, Cutler AC, editors. New consitutionalism and world order. Cambridge, UK: Cambridge University Press; forthcoming.

12. Schneiderman D. Constitutionalizing economic globalization: Investment rules and democracy's promise. Cambridge, UK: Cambridge University Press; 2008.

13. Franck S. Foreign direct investment, investment treaty arbitration, and the rule of law. Pacific McGeorge Global Business and Development Law Journal. 2007; 19(2):337-373.

14. Möslein F, Riesenhuber K. Contract governance-A draft research agenda. European Review of Contract Law. 2009;5(3):248-289.

15. Azeem Z. Issues of arbitration in the international law of investment. Business Recorder. 3 March 2011:2.

16. Schill SW. The multilateralization of international investment law. Cambridge, UK: Cambridge University Press; 2009.

17. Burke-White W, Von Staden A. Private litigation in a public law sphere: The standard of review in investor-state arbitrations. Yale Journal of Interna- 
tional Law. 2010;35(2):283-346.

18. Gal-Or N. Dispute resolution in international trade and investment law: Privatization of the public? In: Graz J-C, Nölke A, editors. Private transnational governance and its limits. New York, USA, and London, UK: Routledge; 2008, pp. 209-221.

19. Choudhury B. Recapturing public power: Is investment arbitrations engagement of the public interest contributing to the democratic deficit? Vanderbilt Journal of Transnational Law. 2008;41 (3):775-832.

20. Salacuse J. BIT by BIT: The growth of bilateral investment treaties and their impact on foreign investment in developing countries. International Lawyer. 1990;24(3):655-675.

21. See Cutler AC. Critical reflections on Westphalian assumptions of international law and organization: A crisis of legitimacy. Review of International Studies. 2001;27(2):133-150 for discussion of the doctrine of international legal personality and the legal status of individuals and corporations.

22. Salcuse J, Sullivan N. Do BITs really work? An evaluation of bilateral investment treaties and their grand bargain. Harvard International Law Journal. 2005;46(1):67-75.

23. Guzman A. Why LDCs sign treaties that hurt them: Explaining the popularity of bilateral investment treaties. Virginia Journal of International Law. 1998; 38(January):639-688.

24. Dolzer R. The impact of international investment treaties on domestic administrative law. New York Journal of International Law and Politics. 2005; 37(4):953-972.

25. See generally, Dezalay Y, Garth B. Dealing in virtue: International commercial arbitration and the construction of a transnational legal order. Chicago, USA, and London, UK: University of Chicago Press; 1996.

26. Braun $T$. Investors as subjects of public international law. In: Tietje $C$, Kraft $G$, Lehmann $M$, editors. General public international law and international investment law: A research sketch on selected issues. Halle (Saale), Germany: International Law Association German Branch Working Group; No: 105, 2011, pp. 43-48.

27. Keohane RO, Nye Jr. JS. Transnational relations and world politics. Cambridge, UK: Cambridge University Press; 1971.

28. Van Apeldoorn B. Cited in: Cutler AC. Legal pluralism as the common sense of transnational legality. In: Cohen E, Cutler AC, editors. Law, contestation, and power in the global political economy; forthcoming.

29. Sweet AS. The new lex mercatoria and transnational governance. Journal of European Public Policy. 2006;13(5):627-646.

30. Lorz $R$. The local remedies rule as part of international law. In: Tietje C, Kraft G, Lehmann M, editors. General public international law and international investment law: A research sketch on selected issues. Halle (Saale), Germany: International Law
Association German Branch Working Group; No: 105; 2011, pp.48-59.

31. Paulsson J. Arbitration without privity. Foreign Investment Review Journal. 1995; 10(2):232-257.

32. Cotula L. Investment contracts and sustainable development: How to make contracts for fairer and more sustainable natural resource investments. London, UK: International Institute for Environment and Development; Natural Resource Issues No. 20, 2010.

33. Schill S. Enabling Private Ordering: Function, Scope and Effect of Umbrella Clauses in International Investment Treaties. Minnesota Journal of International Law. 2009;18:1-97.

34. Preliminary Decision on Jurisdiction of 8 December 1988, ILM 40 (2001), 457.

35. Vicuña F. Of Contracts and Treaties in the Global Market. Max Planck Yearbook of United Nations Law. 2004;8:341-357.

36. Introduction. In: Tietje C, Kraft G, Lehmann $M$, editors. General public international law and international investment law: A research sketch on selected issues. Halle (Saale), Germany: International Law Association German Branch Working Group; No: 105; 2011, pp. 9-28.

37. Report of the Special Representative of the Secretary General on the issue of human rights and transnational corporations and other business enterprises, John Ruggie-Guiding principles on business and human rights: Implementing the United Nations "Protect, Respect and Remedy" Framework. Geneva, Switzerland: United Nations; A/HRC/17/31, 2011. Available from: http://www.ohchr.org/documents/issues/bus iness/A.HRC.17.31.pdf (accessed on 30 April 2013).

38. Quoted in Franck S. Development and outcomes in investment treaty arbitration. Harvard International Law Journal. 2009;50(2):435-489.

39. Venezuela Withdraws from the World Bank's International Centre for the Settlement of Investment Disputes. Milibank Litigation. 30 January 2012:1. Available from: http://www.milbank.com/images/con tent/7/2/7277/Venezuela-Withdraws-From-ICSID-1-30 -2012.pdf (accessed on 30 April 2013).

40. Kaushal K. Revisiting history: How the past matters for the present backlash against the foreign investment regime. Harvard International Law Journal. 2009;50(2):491-534.

41. Laborde G. The case for host state claims in investment arbitration. Journal of International Dispute Settlement. 2010;1(1):97-122.

42. Guzman AM. Review Essay of Sornarajah, The International Law of Foreign Investment. European Journal of International Law. 1995;6(3):612-633.

43. Sonarajah $M$. The international law of foreign investment. Cambridge, UK: Cambridge University Press; 1994.

44. Sonarajah M. State responsibility and bilateral investment treaties. Journal of World Trade. 1986:20 (1):79-98. 
45. For a classic statement of liberal analysis drawing upon rational choice and collective goods theories that invoke transaction-cost analysis to explain the emergence and operations of international legal regimes see Keohane RO. After hegemony: Cooperation and discord in the world political economy. Princeton, USA: Princeton University Press; 1994. For the economic analysis of law, see Posner E. Economic Analysis of Law. Toronto, Canada: Little Brown; 1986; and Thompson A. Applying rational choice theory to international law: The promise and pitfalls. The Journal of Legal Studies. 2002;31(S1):S285-S360. For a critical political economy approach to international economic law and international relations see [4].

46. Vandevelde K. The political economy of a bilateral investment treaty. American Journal of International Law. 1998;92(4):621-641.

47.For the contribution of property and contract laws to economic efficiency, see Frankel T. The legal infrastructure of markets: The role of contract and property law. Boston University Law Review. 1993;43 (4):389-404.

48. See Collins H. Regulating contracts. Oxford, UK: Oxford University Press; 1999 for analysis of the social foundations of contract law.

49. Elkins Z, Guzman AT, Simmons BA. Competing for capital: The diffusion of bilateral investment treaties, 1960-2000. International Organization. 2006; 60(4):811-846.

50. Van Aaken A. International investment law Between commitment and flexibility: A contract theory analysis. Journal of International Economic Law. 2009; 12(2):507-538.

51. Scott R. The law and economics of incomplete contracts. Annual Review of Law and Social Science. 2006;2:279-297.

52. Williamson $\mathrm{OE}$. The economic institutions of capitalism. New York, NY, USA: The Free Press; 1985.

53. Cooley A, Spruyt H. Contracting states: Sovereign transfers in international relations. Princeton, NJ, USA: Princeton University Press; 2009.

54. Other treaties have been analyzed as incomplete contracts, including the Treaty of Rome (see Majone D. Dilemmas of European integration. Oxford, UK: Oxford University Press; 2005) and NAFTA [53]).

55. Vernon R. Sovereignty at bay: The multinational spread of US enterprises. New York, NY, USA: Basic Books; 1971.

56. Hart O. Incomplete contracts and the theory of the firm. Journal of Law, Economics and Organization. 1988;4(1);49-139 and Hart O. Firms, contracts and financial structure. Oxford, UK: Clarendon Press; 1995.

57. Lake D. Anarchy, hierarchy, and the variety of international relations. International Organization. 1996;50(1):1-33.

58. There is some uncertainty as to the actual legal status of the right held by the foreign investor.
See discussion at [9].

59. See Peterson L. Human rights and bilateral investment treaties: Mapping the role of human rights law within investor-state arbitration. Montreal, Canada: International Centre for Human Rights and Democratic Development; 2009 concerning the Russian oil company, Yukos and claims against the Ukrainian government made by Limited Liability Company AMTO.

60. ICSID. Case no. ARB/(AF)/99/2, Award of 11 October 2002, para. 144.

61. ICSID. Case no. ARB/(AF)/00/2, Award of 29 May 2003, paras. 116-122.

62. ICSID. Case no. ARB/01/12, Award of 14 July 2006, paras. 311-312.

63. ICSID. Award of 8 June 2009, [2009] 48 ILM 1039.

64. Claimants Memorial, 10 July 2008; ICSID. Case no. ARB/10/5. 11C 481, Award of 12 January 2011.

65. See Peterson ([59] p. 26, note 59) for a listing of a dozen BIT arbitrations in the water sector.

66. ICSID Case no. ARB/08/19 Award of 30 July 2010.

67.ICSID Case no. ARB/07/17, Award of 21 June 2011.

68. Sweet AS, Grisel F. Transnational investment arbitration: From delegation to constitutionalization? In: Dupuy P-M, Petersman E-U, Francioni, F, editors. Human rights in international investment law and arbitration. Oxford, UK: Oxford University Press; 2009.

69. The General Exceptions in the Canadian FIPA are provided for in Article 10: 1 . Subject to the requirement that such measures are not applied in a manner that would constitute arbitrary or unjustifiable discrimination between investments or between investors, or a disguised restriction on international trade or investment, nothing in this Agreement shall be construed to prevent a Party from adopting or enforcing measures necessary: (a) to protect human, animal or plant life or health; (b) to ensure compliance with laws and regulations that are not inconsistent with the provisions of this Agreement; or (c) for the conservation of living or non-living exhaustible natural resources.

70. The issue of the arbitrators' role as private or public in nature is a very important, but is beyond the scope of this paper and forms the basis of another study currently being conducted by the writer.

71. Waibel M, Kaushal A, Chung K-H, Balchin C, editors. The backlash against investment arbitration. Leiden, The Netherlands: Kluwer Law International; 2010.

72. Hallward-Dreimeier M. Do bilateral investment treaties attract foreign direct investment? Only a bit... and they could bite. Washington, DC, USA: World Bank; Working Paper No. 3121, 2003. 